\title{
Application of Know Want Learning How "KWLH" Techniques to Improve Activities and Learning Outcomes of the Social Subject
}

\author{
Dedy Angger Amriyanto,Warsono,Ketut Prasetyo \\ Basic education, Postgraduate \\ Universitas Negeri Surabaya \\ Surabaya, Indonesia \\ dedyanggeramriyantonew@gmail.com
}

\begin{abstract}
The Physical education in early childhood could provide more chances for student to develop their physical ability and motoric development by a variety of physical exercise. This research aims to develop an ideal lesson plan of physical education which is suitable and worthwhile for early childhood student to develop their physical fitness. The research involved 20 kindergarten students (Age \pm 6 years old) in to 6 times physical education meetings that was conducted using Dick and Carey systematic approach. There are three research instruments that were used in this study, which are one leg stand in balance test, horizontal jump in power test, and hopscotch performance in coordination test. As the result, there are significant difference between pretest and posttest (significant value $<0.05 \%$ ) in every dependent variable. In conclusion, the implementation of such instructions to increase early childhood physical fitness components worked effectively. The instructional objectives were accomplished completely and significantly.
\end{abstract}

\section{Keywords - physical education; early childhood; kindergarten}

\section{INTRODUCTION}

In the education of the world, Learning is a component that momentously, since with good and effective learning, therefore success in a learning performing will high. [1] Environmentally learning which effective is get to utilize studying source our around to be utilized in the teaching and learning process so gets to increase success in learning. Create environmentally studying which well and effective according to a statement [2]

As to establish effective studying environment make the educative participant, be active, the educator shall get to utilize concrete learning media and exact learning method [3].

Base on observation result that researcher does at State Elementary school of First Kemangsen. Balongbendo's district Sidoarjo's Regency, there is some constraint in processes teaching and learning. Educator as teaching is still used discourse method just so students in active processes of teaching and learning be passive and science about material which be taught circumscribed according to science which had by the educator. [4] Educator doesn't use the media learning so the student is less understanding from explaining of the teacher. Students feel bored with the narrow and limited classroom, it can be seen when the teacher explains the material, there are still students who talk to their seatment and there are still students unfocus so they see the right and left.

The learning utilizes the environment as a learning resource that can overcome the student boredom and give an enjoyable atmosphere for student [5]. Based on observational result that done by researcher on pre-cycle by third grade student of Elementary school of First Kemangsen Balongbendo's district Sidoarjo's Regency that is the percentage of the student classical complete just as big as $50 \%$, it hasn't reached the student minimal criterion is $=80 \%$ and for individual thoroughness just as big as $45 \%$, so it hasn't reached the student minimal criterion is as big as $=80 \%$.

Finally, Researcher will apply tech of KWLH to increase activity and the student learning result. The learning tech is developed by [6], a Collaborative learning implementation that uses graphics pilotage (Graphic Organizer). The tech of KWLH has 4 Know Want Learning How're steps that have a purpose to utilize environment as a source of the student studying. [7] In this case is utilized environment as the source of studying as museum search, searching Internet, study tour, archaeology, concrete object, observation is in the studying source such as market, library, a cooperative society, canteen, hospital and the other places that can be observed corresponds to learning material. The tech of KWLH gives the opportunity of the student to find new knowledge without the instruction of teacher to utilize environment as the source of studying and helps the student to increase activity in processes teaching and learning [8].

\section{METHOD}

\subsection{General Background of Research}

The research is executed at State Elementary school of First Kemangsen. Balongbendo's district Sidoarjo's Regency. The research subject the third-grade student of State Elementary school of First Kemangsen in the Social subject in 2016 / 2017 years. The Observational type that utilized by the researcher is CAR (Classroom Action Research) in educational and Social subject learning that has a purpose to get activity or action data that found within the class and to fix learning process at a class in elementary school [9]. CAR has 
severally phase such as planning, action, observation, and reflection. There is the phase for utilized in Classroom Action Research that researcher utilizes model then developed by [10] and explained by [11]

\subsection{Sample of Research}

State Elementary school of First Kemangsen Balongbendo's district Sidoarjo's Regency is beside highway of Krian Balongbendo road that easy arrived by student and student's parent if study at State Elementary school of First Kemangsen. There are 12 teachers that consisting of 7 Civil Servant included headmasters and 5 Non-Civil Servant. The School has to study source such as Co-op, Library, Canteen, Medicine Room, Laboratory.

\subsection{Instrument and Procedures}

The observational procedure consists of two cycles or more in which each cycle is performed 2 meet times. Each cycle has four steps such as 1) planning are researcher plan anything who will be taught about the problem and problemsolving. The researcher instrument are Syllabus, Lesson Plan Module, Student observation sheet, Learning media, Evaluation test of objective and subjective, [14] 2 ) Actions are an action that done by researcher to fix about problem appear, 3 ) observations are collecting and registry database on action has done up to teaching and learning process, and 4) reflection are action researcher to evaluate with observer and colleague friend base on data was collected up to teaching and learning process performing [12]. The researcher tech to collect data utilizes Essay Tech, questionnaire tech, and Documentation Tech.

\subsection{Data Analysis}

Analysis data that utilized by the researcher are analysis qualitative and quantitative data [13]. Qualitative data is a collection of data of pictured from student expression as narasi aims to measure student grasp level or student cognitive aspect student[14]. Analysis of quantitative data is to look for value result of student that can be researched with descriptive. The complete of Student is said completely if up to value as big as $>75$ that established by State Elementary school of First Kemangsen. Balongbendo's districts Sidoarjo's Regency. There is the formula even acquisition assesses to test, according to [15] which is

Value $=\underline{\text { Value Acquired }} \times 100$

Value Maximal

Specified of the complete classical by State Elementary school of First Kemangsen. Balongbendo's districts Sidoarjo's Regency is as big as $80 \%$. The formula to know the complete percentage of learning result according to [16] as follows.

$$
\text { Classical Complete }=\frac{\text { student hascomplete }}{\text { Total student }} \times 100 \%
$$

The formula for calculating student activity, according to
Student Activity $=\frac{\text { Totaly Score which is obtained }}{\text { Maximum Totaly score }}=100 \%$

\section{RESULTS AND DISCUSSIONS}

The results are presented in table 1 and table 2 which will be explained as follows :

Table 1

Data of Student Activity Improvement is in $1^{\text {st }}, 2^{\text {nd }}$, and $3^{\text {rd }}$ Cycle

\begin{tabular}{|c|c|c|c|c|}
\hline \multirow[t]{2}{*}{ No } & \multirow{2}{*}{$\begin{array}{c}\text { Aspects } \\
\text { Observed }\end{array}$} & \multicolumn{3}{|c|}{ Average Score } \\
\hline & & $\begin{array}{c}1^{\text {st }} \\
\text { Cycle }\end{array}$ & $\begin{array}{c}2^{\text {st }} \\
\text { Cycle }\end{array}$ & $\begin{array}{c}3^{\text {st }} \\
\text { Cycle }\end{array}$ \\
\hline 1 & $\begin{array}{l}\text { (Know) } \\
\text { Early student } \\
\text { knowledge }\end{array}$ & 88 & 88 & 100 \\
\hline 2 & $\begin{array}{l}\text { (Want) } \\
\text { Listening } \\
\text { Activity }\end{array}$ & 75 & 75 & 75 \\
\hline 3 & $\begin{array}{c}\text { (Learning) } \\
\text { Question and } \\
\text { Answer } \\
\text { Activity }\end{array}$ & 88 & 100 & 88 \\
\hline \multirow[t]{7}{*}{4} & $\begin{array}{c}\text { (How) } \\
\text { Utilizing the } \\
\text { environment as } \\
\text { a learning } \\
\text { resource }\end{array}$ & 63 & 75 & 100 \\
\hline & $\begin{array}{l}\text { Team Work } \\
\text { activity }\end{array}$ & 50 & 88 & 88 \\
\hline & $\begin{array}{c}\text { Presentation } \\
\text { Activity }\end{array}$ & 75 & 75 & 88 \\
\hline & $\begin{array}{l}\text { Mental } \\
\text { Activity }\end{array}$ & 50 & 75 & 88 \\
\hline & Oral Activity & 75 & 75 & 88 \\
\hline & Total & 564 & 651 & 702 \\
\hline & Percentage \% & 70,5 & 81,3 & 87,7 \\
\hline
\end{tabular}

Based on data in table 1 , that on the $1^{\text {st }}$ cycle the percentage of student activity success is $70 \%$. Aspects of how in teamwork activity there are still some passive students in discussions with their teammates. Some teams are discussing the group observation tasks given by the teacher. Aspects of How in the mental activity of student there are still some students who are passive not the daring asking question to the teacher and in the presentation never participate in answering questions posed by friends of another team. In the 2nd cycle, the percentage of student activity success increased to $81 \%$. Aspects of How in the oral activity there are still students who still use informal language and there are still students who speak with their seatmate. In the $3^{\text {rd }}$ Cycle, the percentage of student activity success increased to $88 \%$. On the Aspect of Want in listening activity, students sometimes are unfocused on the lessons explained by the teacher. 
Table 2

Data for Student Learning Result is in $1^{\text {st }}, 2^{\text {nd }}$, and $3^{\text {rd }}$ Cycle

\begin{tabular}{|c|c|c|c|}
\hline & $1^{\text {st }}$ Cycle & $2^{\text {nd }}$ Cycle & $3^{\text {rd }}$ Cycle \\
\hline Total & 1.530 & 1.729 & 1.756 \\
\hline Average of Class & 77 & 86 & 88 \\
\hline Students Total & 12 & 15 & 18 \\
\hline $\begin{array}{c}\text { Total of Student } \\
\text { is not complete }\end{array}$ & 8 & 5 & 2 \\
\hline $\begin{array}{c}\text { Complete } \\
\text { Percentage \% }\end{array}$ & $60 \%$ & $75 \%$ & $90 \%$ \\
\hline
\end{tabular}

Based on the 2nd table above, student learning result has increased in each cycle. That is proved by the percentage of student learning result on $1^{\text {st }}$ cycle reach $60 \%$ while on $2^{\text {nd }}$ cycle have increased be $75 \%$. In addition, on the $3^{\text {rd }}$ cycle also have increased be $90 \%$.

\section{CONCLUSION}

Based on the analysis, the research result and discussion can be concluded as follows:

1. Based on the learning result by the application of Know Want Learning Techniques in the third grade with materials of sale and purchase in each cycle has increased. The $1^{\text {st }}, 2^{\text {nd }}$ and $3^{\text {rd }}$ cycles show increasing with the completeness of student cognitive learning result. The $1^{\text {st }}$ cycle is $60 \%$, increased to $75 \%$ on $2^{\text {nd }}$ cycle and $90 \%$ on $3^{\text {rd }}$ cycle.

2. Student activity during the learning process by applying Know Want Learning How Technique in third grade the material of buying and selling happened on $1^{\text {st }}$, $2^{\text {nd }}$, and $3^{\text {rd }}$ cycle. In the $1^{\text {st }}$ cycle get a percentage of $70 \%, 2^{\text {nd }}$ cycle get percentage equal to $81 \%$ and the $3^{\text {rd }}$ cycle gets percentage equal to $87 \%$.

\section{REFERENCES}

[1] Sanjaya, Teori Pembelajaran Kreatif dan Inovatif. Surabaya: Aksara, 2006.

[2] S. Azwar, Sikap Manusia dan Dasar Dasar Psikologi. Yogyakarta: Pustaka Pelajar, 2005.

[3] Anita, Pembelajaran Terpadu Materi Pokok PGSD. Jakarta: Universitas Terbuka, 2007.

[4] H. Wagner, Organizational Behavior Securing Competitive Advantage. Francis: Routledge, 2010.

[5] A. Machtar, Pengembangan Berfikir dan Nilai dalam Pendidikan IPS. Bandung: Gelar Pustaka Mandiri, 2004.

[6] D. Ogle, Pendidikan, Konsep, dan Aplikasi. Malang: Gelar Pustaka Mandiri, 1986.

[7] Warsono, Pembelajaran Aktif Teori dan Asesmen. Bandung: PT Remaja Rosdakarya., 2012.

[8] D. Mertens, Research And Evaluation In Education And Psychology. United States of America: Sage Publications, 2010.

[9] Sudjana, Pengantar Evaluasi Pendidikan. Jakarta: PT Remaja Rosdakarya, 2004.

[10] R. Kemmis, S \& Mc. Tanggart, The Action Research Planner. Australia: Deakin University Press, 1992.

[11] S. Arikunto, Prosedur Penelitian Suatu Pendekatan Praktik. Jakarta: Rineka Cipta, 2006.

[12] E. Dale, Ilmu Pengetahuan Teknologi Komunikasi. Malang, 1989.

[13] C. \& Sun, Teaching Science Through Discover. Merril: Publising Company., 1975.

[14] D. Howitt, Introduction to SPSS Statistics in Psychology. England: Pearson, 2011.

[15] Sugiyono, Metodologi Penelitian Kualitatif. Jakarta: Kencana, 2010.

[16] Kunandar, Langkah Mudah Penelitian Tindakan Kelas Sebagai Pengembangan Profesi Guru. Jakarta: PT Raja Grafindo Persada, 2013. 